\title{
HOW FINANCIAL LITERACY EFFECT FINANCIAL ATTITUDES UNDER CRISIS CONDITIONS?
}

\author{
DOI: 10.17261/Pressacademia.2019.1144 \\ PAP-IFC- V.10-2019(12)-p.62-67
}

\section{Tutku Tuncali Yaman}

Beykent Univeresity, Management Information Systems Department, Sariyer, Istanbul, Turkey tutkuyaman@beykent.edu.tr, ORCID:0000-0001-8742-2625

\section{To cite this document}

Tuncali Yaman, T., (2019). How financial literacy effect financial attitudes under crisis conditions? PressAcademia Procedia (PAP), V.10, p.62-67.

Permemant link to this document: http://doi.org/10.17261/Pressacademia.2019.1144

Copyright: Published by PressAcademia and limited licenced re-use rights only.

\begin{abstract}
Purpose- Since 2018 Q3, economic conditions in Turkey have showed a drastic change (The World Bank, 2019).This situation has made Turkish residents to take serious financial decisions and changed their attitudes and perceptions according to their financial situations. In this study, relationship with different financial perceptions/attitudes and financial literacy is aimed to investigate.

Methodology- In line with the research purpose, data collected from 152 Turkish residents in order to measure their financial literacy and understand financial attitudes. OECD's Financial Literacy Questionnaire is used as the data collection tool for financial literacy (OECD, 2018) and TEPAV's (The Economic Policy Research Foundation of Turkey) Welfare Monitoring Survey Questionnaire is used for measuring effects of current economic crisis on financial perspectives and attitudes.

Findings- In line with the purpose of the research, frequency, and factor and correlation analysis was performed. Overall financial literacy score of total group and characteristics of well-performed group are consistent with OECD's the latest published results for Turkey. When the level of financial literacy is broken down according to demographic characteristics, the best performed group in terms of financial literacy is generally male, single, middle-age group, with a high degree of education, income and socio-economic status. In addition to general investigation of financial literacy, six different crisis-affected groups are defined via factor analysis according to their attitudes and perceptions under crisis conditions. It is seemed that different groups have different financial literacy scores and attitudes under current economic conditions.

Conclusion- According to main finding of the study, higher scores of literacy bring economic well-being. Residents with higher financial literacy scores are not much troubled by the crisis. Most of them are worried only with the domestic economic environment. In both domestic and foreign literature, there are many studies on financial literacy. On the other hand, there is no academic research showing the connection between the financial attitudes and viewpoints of Turkish citizens under crisis conditions with their financial literacy. In this context, the study's contribution to literature is evaluated
\end{abstract}

Keywords: Financial literacy, Financial attitudes, Financial behavior, Turkey, Financial crisis JEL Codes: G53, G01, D14

\section{INTRODUCTION}

After the currency crisis emerged in third quarter of 2018, there has been a dramatic change in economic conditions in Turkey (World Bank 2019).This situation has led to serious financial decisions being taken by Turkish citizens. Hung, et.al (2009) stated that the less financially literate may be more likely to unknowingly commit financial mistakes, less likely to engage in recommended financial practices, and less likely to be able to cope with sudden economic shocks. In order to investigate effects of financial crisis in the perceptions and attitudes of different groups with varying financial literacy levels OECD INFE's Financial Literacy Questionnaire is used as the data collection tool for (OECD, 2018). In addition to that, TEPAV's (The Economic Policy Research Foundation of Turkey) Welfare Monitoring Survey Questionnaire is used for measuring effects of current economic crisis on financial perspectives and attitudes of Turkish residents. (TEPAV, 2008). There are many studies on financial literacy in both domestic and foreign literature. On the other hand, there is no academic research that demonstrates the relation of Turkish residents' financial attitudes and perspectives with their financial literacy under crisis conditions. The contribution of the study to the literature is evaluated in this sense.

The rest of the paper is organized as follows: Section 2 provides a glance of related studies in financial literacy. Section 3 explains the data collection method and the findings are presented in Section 4. Finally, conclusion of the study detailed in Section 5.

\section{LITERATURE REVIEW}

Before continue on to literature review, it is useful to include a current definition of the term financial literacy. The OECD INFE has defined the term as: 'A combination of awareness, knowledge, skill, attitude and behavior necessary to make sound financial decisions and ultimately achieve individual financial wellbeing.' Financial Inclusion is the process of ensuring access to appropriate financial products and services 
needed by vulnerable groups such as weaker sections and low-income groups at an affordable cost in a fair and transparent manner by mainstream institutional players.

In many countries, financial literacy has been tried to be determined by different groups and with different scales. In order to examine the general statistics with a search in EBSCO database, it has been found that more than 7500 academic papers were publishedin academic journals when the search was made with the keyword "financial literacy" since 2010. With this sense, it would be better for readers who want to access the current literature on this subject are recommended to refer to cited sources: (Tavares, et.al, 2019; Compen, et. al, 2019; Tetik, 2019; Nanda and Samanta, 2018; Amagir, et.al, 2018; Eren and Aydemir, 2014).

In this section, in line with the purpose and scope of the research, it is considered to be accurate in terms of comparison to include

Financial Literacy and Access Index (Finansal Okuryazarlık ve Erişim Endeksi) results, which is using the OECD INFE'sadapted scale in Turkey. This study is measuring the level of financial literacy in Turkey periodically. In cooperation of TEB (Turkey Economy Bank) and Bogazici University Analytical Insights Center developed this Financial Literacy and Access Index. The Index, which was developed by using the OECD INFE survey, was first prepared in 2013 and is carried out annually in a continuous manner and the results are shared with the public.2018 results were published as of the date of this study was prepared (TEB, 2018).According to 2018 results of the study, Consumer Financial Literacy Index was calculated as 61,5. This figure shows a slight increase from 60,8, which is the Financial Literacy Index value of 2017 , and constitutes the last link of a consistent increase from 59,4 in 2014 to 2018 . When the level of financial literacy is broken down according to demographic characteristics, the most advantageous group in terms of financial literacy is generally male, single, 25-44 age group, with a highdegree of education, income and socio-economic status, and mostly managers, business owners, paid and self-employed experts (lawyers, doctors, architects, engineers, etc.), and non-executive officers / technical staff / experts. On the other hand, it is observed that the disadvantaged group in terms of financial literacy is generally composed of women, married, over 45 years of age, relatively low education, income and socio-economic status and mostly unemployed, housewives, irregular workers and students. The calculation methodology of the index is not included in the report.

The most recent results published by the OECD are the 2017 report on the G20 countries (OECD, 2017). When it looks at the results obtained here for Turkey: data from 3003 people were collected between May and June 2015 with stratified multistage random sampling method, and the average inflation rate was $8 \%$ during the field study. When we looked into average scores; Average financial knowledge score(max 7): 4,6, Average financial behavior score $(\max 9): 4,8$, Average financial attitude score( $\max 5): 3$ and Average financial literacy score(max 21$)$ : 12,5 (G20 average is 12.7 )

\section{DATA AND METHODOLOGY}

In order to investigate research purpose stated in introduction section, data collected from more than 150 Turkish residents in order to measure their financial literacy and understand financial attitudes and perpectives in current economic conditions. Randomly selected study sample residing in various provinces of Turkey constitutes 152 people who were accepted to participate in the online survey. For descriptive purposes, there is no age limit for the participants; the participation of individuals of all ages, genders and various socio-demographic conditions is welcomed. The universe of the research consists of the people who make the financial decisions in their households. All participants of the study meet this requirement. OECD's Financial Literacy Questionnaire is used as the data collection tool for financial literacy parameters (OECD, 2018). In addition to financial literacy scale, TEPAV's (The Economic Policy Research Foundation of Turkey) Welfare Monitoring Survey Questionnaire is used for measuring effects of current economic crisis on financial perspectives and attitudes. (TEPAV, UNICEF and World Bank, 2010). With reliability purposes, before conducting the final version of the translated questionnaire of OECD, a face-to-face pilot study with 30 respondents was realized in Istanbul. After incomprehensible sentences were corrected and irrelevant questions were excluded, the form was adapted to its online version and sent to potential respondents via e-mail. In addition to pilot study, questionnaire was enriched with 3 academics' opinions from the field.

Data was collected between September and October 2019. Finally, out of 157, a totally filled 152 questionnaires were accepted for the analysis. Before continuing with the findings of the study it is important to state the limitations of the study. Gained descriptive results are limited with 152 people and cannot be expanded to all Turkish residents. Also this study depends on the respondents' self-reported data.

According to OECD's methodology, which was also followed in this study, financial literacy assessment consists of four main dimensions (OECD, 2018):

1. The financial knowledge score is computed as the number of correct responses to the seven financial knowledge questions, which includes identification of interest, understanding impact of inflation on spending power and implication of compounding, and simple interest calculation.

2. The financial behavior score is computed as a count of the number of "financially savvy" behaviors relating to budgeting, active saving, avoiding borrowing to make ends meet choosing products, keeping watch on financial affairs, striving to achieve goals, making considered purchases, paying bills on time.

3. The financial attitude score is computed as the average response across three attitude questions:

- I find it more satisfying to spend money than to save it for the long term

- Money is there to be spent

- I tend to live for today and let tomorrow take care of itself

4. The overall financial literacy score is obtained as the sum of the three previous scores (financial knowledge, financial behavior and financial attitudes. 
In line with the purpose of the research, frequency, factor and correlation analysis was performed. IBM SPSS (Statistical Package for SocialSciences) 20.0 was used to conduct statistical analysis. Detailed findings of the study will be represented in next section below.

\section{FINDINGS}

The demographic characteristics of 152 participants were analyzed to determine the general structure of the sample. Accordingly, with descriptive purposes, frequency analysis of demographics and attitudes of the participants in the sample are given in the first section below.

\subsection{Descriptives}

As a start with frequencies of fundamental demographics; 79 of the participants were female and 73 were male. 29 people are between 20 29 years, 71 people are between 30-39 years, 29 people are between $40-49$ years, 17 people are between $50-59$ years, 6 people are between 60 and over. When the distribution according to educational level is examined, it is seen that 32 people are secondary and high school graduates, 73 are university graduates and 47 have a post-graduate education level. Approximately $84 \%$ of the participants live in large cities and $55 \%$ are in-paid employee. 20 of the participants had a monthly income of $2000 \mathrm{TL}$ and below, 52 of them were $2000-4000$ TL, 34 of them were 4000-6000 TL, 46of them earned $6000 \mathrm{TL}$ or more. Detailed figures are given in Table 1 below.

Table 1: Demographics of Participants of the Study

\begin{tabular}{llcc}
\hline & \multicolumn{1}{c}{ Demographics } & Frequency & $\%$ \\
\hline Gender & Female & 79 & $52 \%$ \\
& Male & 73 & $48 \%$ \\
\hline Age & $20-29$ & 29 & $19,1 \%$ \\
& $30-39$ & 71 & $46,7 \%$ \\
& $40-49$ & 29 & $19,1 \%$ \\
& $50-59$ & 17 & $11,2 \%$ \\
& Over 60 & 6 & $4,0 \%$ \\
\hline Location & A town (15 000 to about 100 000 people) & 8 & $5,3 \%$ \\
& A city (100 000 to about 1 000 000 people) & 17 & $11,2 \%$ \\
& A large city (with over 1 000 000 people) & 127 & $83,6 \%$ \\
\hline Secondary school & 2 & $1,3 \%$ \\
& High school & 30 & $19,7 \%$ \\
& University-level education & 73 & $48 \%$ \\
& Post-graduate education & 47 & $30,9 \%$ \\
\hline Income & Under 2000 TL & 20 & $13,2 \%$ \\
& 2000-4000 TL & 52 & $34,2 \%$ \\
& 4000-6000 TL & 34 & $22,4 \%$ \\
& Over 6000 TL & 46 & $30,3 \%$ \\
\hline Working status & Self-employed & 22 & $14,5 \%$ \\
& In paid employment & 83 & $54,6 \%$ \\
& Housewife & 4 & $2,6 \%$ \\
& Retired & 16 & $10,5 \%$ \\
& Student & 16 & $10,5 \%$ \\
& Not working and looking for work & 4 & $4,6 \%$ \\
& Not working and not looking for work & $2,7 \%$ \\
\hline
\end{tabular}

By following OECD's methodology, financial literacy assessment scores for four main dimensions are calculated. Detailed figures according to different demographic groups and total scores illustrated below in Table 2. Financial knowledge score of participants is calculated as 4,6 (in a range between 0 and 7). Financial behavior score is 4,7 (in a range between 0 and 7), Financial attitude score is 0,69 (in a range between 0 and 1 ) and overall financial literacy score is 9,94 (in a range between 0 and 15).

Table 2: Financial Literacy Scores According to Demographics

\begin{tabular}{|c|c|c|c|c|c|}
\hline & Demographics & $\begin{array}{c}\text { Financial } \\
\text { knowledge (R:0-7) }\end{array}$ & $\begin{array}{c}\text { Financial } \\
\text { behavior (R:0-7) }\end{array}$ & $\begin{array}{c}\text { Financial attitude } \\
\text { (R:0-1) }\end{array}$ & $\begin{array}{l}\text { Overall financial } \\
\text { literacy (R:0-15) }\end{array}$ \\
\hline \multirow[t]{2}{*}{ Gender } & Female & 4,53 & 4,77 & 0,72 & 10,03 \\
\hline & Male & 4,6 & 4,62 & 0,65 & 9,87 \\
\hline \multirow[t]{3}{*}{ Age } & $20-29$ & 4,1 & 5,1 & 0,56 & 9,77 \\
\hline & $30-39$ & 4,68 & 4,73 & 0,69 & 10,1 \\
\hline & $40-49$ & 4,62 & 4,55 & 0,77 & 9,94 \\
\hline \multirow[t]{4}{*}{ Education } & Secondary school & 4 & 3,5 & 0,83 & 8,33 \\
\hline & High school & 4,63 & 4,47 & 0,69 & 9,79 \\
\hline & University-level education & 4,51 & 4,53 & 0,67 & 9,71 \\
\hline & Post-graduate education & 4,64 & 5,15 & 0,7 & 10,49 \\
\hline Income & Under $2000 \mathrm{TL}$ & 4,6 & 4,05 & 0,65 & 9,3 \\
\hline
\end{tabular}




\begin{tabular}{ccccc}
$2000-4000 \mathrm{TL}$ & 4,31 & 4,4 & 0,61 & 9,32 \\
$4000-6000 \mathrm{TL}$ & 4,68 & 4,53 & 0,79 & 10 \\
Over 6000 TL & 4,76 & 5,43 & 0,71 & 10,91 \\
\hline TOTAL & $\mathbf{4 , 6}$ & $\mathbf{4 , 7}$ & $\mathbf{0 , 6 9}$ & $\mathbf{9 , 9 4}$ \\
\hline
\end{tabular}

According to financial knowledge scores; male, middle-aged, relatively highly educated and high-income respondents performed slightly better. Younger females with high education and income level gained higher scores in terms of financial behavior and attitude. The most advantageous group in terms of financial literacy is generally male, 20-50 age group, with a high degree of education, income and socioeconomic status. This result is consistent with OECD's results in 2018

Some of the ranges of the calculated scores differ from OECD figures. The main reason for stated difference is removal of some questions by experts according to their irrelevancy. For comparative purposes, gained scores are indexed to OECD ranges. Indexed figures showed in Table 3 below. According to overall financial literacy score of the participants of the study is slightly higher than OECD's results in 2018 (12,5 vs 13,92).

\subsection{Inferential Results}

Before going further with detailed analysis, correlation analysis is performed in order to understand relationships between different financial literacy dimensions. According to correlation coefficients, there is not a significant correlation between financial knowledge and behavior and attitude. Statistically significant positive correlation is found between overall financial literacy and all other dimensions.

Table 3: Indexed Financial Literacy Scores According to Demographics

\begin{tabular}{|c|c|c|c|c|c|}
\hline & Demographics & $\begin{array}{c}\text { Financial } \\
\text { knowledge (R:0-7) }\end{array}$ & $\begin{array}{c}\text { Financial } \\
\text { behavior (R:0-9) }\end{array}$ & $\begin{array}{c}\text { Financial attitude } \\
\text { (R:0-5) }\end{array}$ & $\begin{array}{l}\text { Overall financial } \\
\text { literacy (R:0-21) }\end{array}$ \\
\hline \multirow[t]{2}{*}{ Gender } & Female & 4,53 & 6,13 & 3,6 & 14,04 \\
\hline & Male & 4,6 & 5,94 & 3,25 & 13,82 \\
\hline \multirow[t]{5}{*}{ Age } & $20-29$ & 4,1 & 6,56 & 2,8 & 13,68 \\
\hline & $30-39$ & 4,68 & 6,08 & 3,45 & 14,14 \\
\hline & $40-49$ & 4,62 & 5,85 & 3,85 & 13,92 \\
\hline & $50-59$ & 4,82 & 5,59 & 3,65 & 13,86 \\
\hline & Over 60 & 4,4 & 4,63 & 3,35 & 12,14 \\
\hline \multirow[t]{4}{*}{ Education } & Secondary school & 4 & 4,50 & 4,15 & 11,66 \\
\hline & High school & 4,63 & 5,75 & 3,45 & 13,71 \\
\hline & University-level education & 4,51 & 5,82 & 3,35 & 13,59 \\
\hline & Post-graduate education & 4,64 & 6,62 & 3,5 & 14,69 \\
\hline \multirow[t]{5}{*}{ Income } & Under $2000 \mathrm{TL}$ & 4,6 & 5,21 & 3,25 & 13,02 \\
\hline & $2000-4000 \mathrm{TL}$ & 4,31 & 5,66 & 3,05 & 13,05 \\
\hline & $4000-6000 \mathrm{TL}$ & 4,68 & 5,82 & 3,95 & 14,00 \\
\hline & Over $6000 \mathrm{TL}$ & 4,76 & $6,98^{*}$ & 3,55 & $15,27^{*}$ \\
\hline & TOTAL & 4,6 & 6,04 & 3,45 & 13,92 \\
\hline
\end{tabular}

*Chi-square test was performed and values are found statistically significant in 0,05 alpha level.

Table 4: Correlation Analysis of Financial Literacy Dimensions

\begin{tabular}{lcccc}
\hline \multicolumn{1}{c}{ Crisis-affected Groups } & Financial knowledge & Financial behavior & Financial attitude & Overall financial literacy \\
\hline Financial knowledge & 1 &,- 122 &,- 057 & $.431^{* *}$ \\
Financial behaviour & & 1 & $.212^{* *}$ & $.827^{* *}$ \\
Financial attitude & & & 1 & $.322^{* *}$ \\
Overall financial literarcy & & & 1 \\
\hline
\end{tabular}

** Statistically significant in 0,01 alpha level.

In order to identify different perspectives and attitudes of participants in crisis conditions TEPAV's (The Economic Policy Research Foundation of Turkey) Welfare Monitoring Survey Scale is used as a measurement tool. The data collected through “TEPAV's Welfare Monitoring Survey Scale" formed crisis-affected groups were subjected to factor analysis. After defining different groups with different perspectives and attitudes, their relation with financial literacy can be investigated. Prior to analysis, Cronbach Alpha value of the scale was investigated for reliability purposes. Alpha value of the scale is 0,903 and it is found as sufficient for further analysis. Before performing exploratory factor analysis with the data, Kaiser Meyer Olkin (KMO) sampling adequacy value and Bartlett sphericity test statistics were checked. KMO value of the scale used in the study is found as 0.771 and Bartlett's sphericity test statistic is $\chi^{2}: 1589,32$, d.f.:253, p:0,00. KMO value of the scale has a very high sampling adequacy and Bartlett sphericity test findings showed that the items of the scale were correlated enough to measure our case together. The results of the explanatory factor analysis performed with Varimax rotation by allowing a free number of factors showed that the scale items are formed in six dimensions. The first component explained $25,05 \%$ of the scale variance alone, the second approximately $14 \%$, the third $7,65 \%$, the fourth $7.05 \%$, the fifth $5.85 \%$ and the sixth $\% 4,92$; and the cumulative variance explanation percentage is quite high and $64,25 \%$. Considering the figures of factor loads belonging to each component and the conceptual significance of the items, it was seen that the components could be a potential crisis-affected group and these groups were named according to represented statements from the scale. 
Group 1- Outage: "I had a water cut because I couldn't pay the bill", "I had a power outage because I couldn't pay the bill", "I had a gas cut because I couldn't pay the bill","I had an internet outage because I couldn't pay the bill"

Group 2 - Expense cutters :"I prefer cheaper food products","I prefer cheaper non-food products", "I meet less with my friends", "I left / postponed my educational expenses such as language / computer courses", "I participate less in social and cultural activities (such as going to cinema, theater, buying magazines)"

Group 3 - Distressed: "I reduced my food consumption”, "I do not buy anything except food”, "I changed my transportation preference”, "I use IT services less", "I seldom see doctors"

Group 4 - Concerned: "I feel my income is diminishing", "I'm trying to reduce my spending", "I'm trying to save money", "I feel economic insecurity", "I think the income I earn from my own business is decreasing"

Group 5 - Crisis opportunist: "I am investing in gold", "I keep my money in a savings account"

Group 6 - Pleasant: "I find the economic measures taken as sufficient", "I save my money in domestic currency (TL)"

In order to understand characteristics of defined groups, the prominent categories on each variable basis were considered as descriptive characteristics. Demographic characteristics and prominent characteristics are given in Table 5 in order to conceptually define the 6 groups identified for this purpose. In each group, the characteristics of group were preferred more than others were accepted as characteristic of the related group and highlighted in the Table 5 below.

When sample sizes are checked; "Outage", "Distressed" and "Pleasant" groups seem underrepresented and result can be accepted as qualitative. Therefore, scores of these underrepresented groups will not be discussed in the rest of the paper. "Expense cutters" group consist of 30-39 aged men with mostly university level education and average income. Middle-aged, high-income females with high education level represent "Concerned" group. There are more males in "Crisis opportunist" group; these men are mostly middle-aged with average education and income level.

Table 5: Demographics of Crisis-affected Groups

\begin{tabular}{|c|c|c|c|c|c|c|c|}
\hline & Demographics & $\begin{array}{c}\text { Outage } \\
n: 7\end{array}$ & $\begin{array}{c}\text { Expense } \\
\text { cutters } n: 29\end{array}$ & $\begin{array}{c}\text { Distressed } \\
\mathrm{n}: 5\end{array}$ & $\begin{array}{c}\text { Concerned } \\
\mathrm{n}: 75\end{array}$ & $\begin{array}{c}\text { Crisis opportunist } \\
\mathrm{n}: 22\end{array}$ & $\begin{array}{c}\text { Pleasant } \\
\text { n:14 }\end{array}$ \\
\hline \multirow[t]{2}{*}{ Gender } & Female & $43 \%$ & $59 \%$ & $20 \%$ & $59 \%$ & $45 \%$ & $29 \%$ \\
\hline & Male & $57 \%$ & $41 \%$ & $80 \%$ & $41 \%$ & $55 \%$ & $71 \%$ \\
\hline \multirow[t]{5}{*}{ Age } & $20-29$ & $29 \%$ & $17 \%$ & $0 \%$ & $21 \%$ & $23 \%$ & $7 \%$ \\
\hline & $30-39$ & $29 \%$ & $48 \% *$ & $80 \%$ & $51 \% *$ & $32 \%$ & $43 \%$ \\
\hline & $40-49$ & $14 \%$ & $17 \%$ & $0 \%$ & $13 \%$ & $36 \%$ & $36 \%$ \\
\hline & $50-59$ & $29 \%$ & $7 \%$ & $20 \%$ & $11 \%$ & $9 \%$ & $14 \%$ \\
\hline & Over 60 & $0 \%$ & $10 \%$ & $0 \%$ & $4 \%$ & $0 \%$ & $0 \%$ \\
\hline \multirow[t]{4}{*}{ Education } & Secondary school & $0 \%$ & $3 \%$ & $0 \%$ & $1 \%$ & $0 \%$ & $0 \%$ \\
\hline & High school & $43 \%$ & $24 \%$ & $20 \%$ & $12 \%$ & $23 \%$ & $36 \%$ \\
\hline & University-level education & $57 \%$ & $45 \% *$ & $60 \%$ & $47 \%$ & $59 \% *$ & $36 \%$ \\
\hline & Post-graduate education & $0 \%$ & $28 \%$ & $20 \%$ & $40 \%$ & $18 \%$ & $29 \%$ \\
\hline \multirow[t]{4}{*}{ Income } & Under $2000 \mathrm{TL}$ & $43 \%$ & $14 \%$ & $40 \%$ & $12 \%$ & $9 \%$ & $0 \%$ \\
\hline & $2000-4000 \mathrm{TL}$ & $29 \%$ & $41 \%$ & $60 \%$ & $29 \%$ & $36 \%$ & $36 \%$ \\
\hline & $4000-6000 \mathrm{TL}$ & $14 \%$ & $38 \%$ & $0 \%$ & $23 \%$ & $18 \%$ & $7 \%$ \\
\hline & Over $6000 \mathrm{TL}$ & $14 \%$ & $7 \%$ & $0 \%$ & $36 \% *$ & $36 \%$ & $57 \%$ \\
\hline
\end{tabular}

$* \overline{C h i-s q u a r e ~ t e s t ~ w a s ~ p e r f o r m e d ~ a n d ~ v a l u e s ~ a r e ~ f o u n d ~ s t a t i s t i c a l l y ~ s i g n i f i c a n t ~ i n ~ 0,05 ~ a l p h a ~ l e v e l . ~}$

Some of crisis-affected groups showed better performance in terms of financial literacy dimensions scores. In terms of financial knowledge scores, none of the groups with representative sample size are showed different performance. Financial behavior scores of "Concerned" group is relatively higher than the others. The same performance is detected for financial attitude and overall financial literacy scores of this group. In addition to "Concerned" group, financial attitude score of "Crisis opportunist" is slightly higher than other groups. Detailed figures are showed in Table 6 below.

Table 6: Financial Literacy Scores of Crisis-affected Groups

\begin{tabular}{lcccc}
\hline Crisis-affected Groups & $\begin{array}{c}\text { Financial knowledge } \\
\text { (R:0-7) }\end{array}$ & $\begin{array}{c}\text { Financial behavior } \\
\text { (R:0-7) }\end{array}$ & $\begin{array}{c}\text { Financial attitude } \\
\text { (R:0-1) }\end{array}$ & $\begin{array}{c}\text { Overall financial } \\
\text { literacy (R:0-15) }\end{array}$ \\
\hline Outage & 4,86 & 4,29 & 0,48 & 9,62 \\
Expense cutters & 4,48 & 3,86 & 0,62 & 8,97 \\
Distressed & 4,6 & 3,4 & 0,47 & 8,47 \\
Concerned & 4,56 & $\mathbf{5 , 1 2}$ & $\mathbf{0 , 7 3}$ & $\mathbf{1 0 , 4 1}$ \\
Crisis opportunist & 4,64 & 4,41 & $\mathbf{0 , 7 0}$ & 9,74 \\
Pleasant & 4,50 & 5,29 & 0,74 & $\mathbf{1 0 , 5 2}$ \\
\hline
\end{tabular}




\section{CONCLUSION}

In this study, it is aimed to investigate relationship with financial perceptions/attitudes and financial literacy under crisis conditions. After defined different crisis-affected groups with their attitudes, perceptions and demographical characteristics with their financial literacy scores following findings can be generalized as:

- $\quad$ Overall financial parameters are considered moderate in total group.

- $\quad$ Financial behavior and attitude scores are generally higher in middle-aged females.

- The best-performed group in terms of financial literacy is generally male, single, middle-age group, with a high degree of education, income and socio-economic status. This result is consistent with OECD's 2017 results.

- $\quad$ Financial knowledge has a positive correlation with education level

- All financial parameters are increasing with income level

- Share of "Concerned" group (49\%) is the highest. It consists female, middle age, university level educated, average income level people with high financial literacy scores.

- Higher literacy scores bring financial well-being. These people are not much affected from crisis as other groups. Most of them only concerned about general economic conditions.

- The most effected groups are "Outage" and "Distressed" but their share in the research sample are very small. In order to represent these people and measure effects of the economic conditions, a focused study can be arranged with higher sample size.

- "Pleasants" and "Crisis Opportunists" have relatively higher income comparing with other groups. Their financial literacy and knowledge scores are also higher.

For further studies, underrepresented groups can be focused for research. By representing these disadvantaged groups well, detailed econometric analysis can be performed in order to understand cause and effects of economic conditions on people's perceptions and financial attitudes along with financial literacy scores.

\section{REFERENCES}

Amagir, A., Groot, W., Maassen van den Brink, H., \& Wilschut, A. (2018). A review of financial-literacy education programs for children and adolescents. Citizenship, Social and Economics Education, 17(1), 56-80.

Aren, S., \& Dinç Aydemir, S. (2014). A literature review on financial literacy. Finansal Araştırmalar ve Çalışmalar Dergisi. 6(11), 33-49.

Compen, B., De Witte, K., \& Schelfhout, W. (2018). The role of teacher professional development in financial literacy education: A systematic literature review. Educational Research Review. 26, 16-31.

Hung, A., Parker, A. M., \& Yoong, J. (2009). Defining and measuring financial literacy. Retrieved from https://papers.ssrn.com

Nanda, A. K., \& Samanta, S. (2018). Mainstreaming tribals through financial literacy-a review of literature. International Journal of Social Economics, 45(2), 437-444.

OECD. (2017).G20/OECD INFE report on adult financial literacy in G20 countries. Retrieved fromhttp://www.oecd.org/daf/fin/financialeducation/G20-OECD-INFE-report-adult-financial-literacy-in-G20-countries.pdf

OECD. (2018).OECD/INFE toolkit for measuring financial literacy and financial inclusion. Retrieved from http://www.oecd.org/daf/fin/financial-education/2018-INFE-FinLit-Measurement-Toolkit.pdf

Tavares, F. O., Almeida, L. G., \& Cunha, M. N. (2019). Financial Literacy: Study of a University Students Sample. International Journal of Environmental and Science Education, Vol. 14, No. 9, 499-510.

TEB. (2018). Türkiye'de Finansal Okuryazarlık ve Erişim2018. Retrieved from https://www.teb.com.tr/upload/PDF/TEB-FOE-Rapor2018_website.pdf

TEPAV. (2008). Ekonomik Kriz Turkiye'de Ailelerin Refahini Etkiliyor. Retrieved from https://www.tepav.org.tr/upload/files/1271243687r8014

The World Bank. (2019).Turkey data. Retrieved from https://data.worldbank.org/country/turkey

Tetik, N. (2019). Türkiye'nin finansal okuryazarlik düzeyi: literatür taramasi ve sonuçlarin değerlendirilmesi. Electronic Turkish Studies, 14(6), 3505-3524. 